\title{
Early performance of planted Nothofagus dombeyi and Nothofagus alpina in response to light availability and gap size in a high-graded forest in the south-central Andes of Chile
}

\author{
Respuesta temprana de plantaciones de Nothofagus dombeyi y Nothofagus alpina a la disponibilidad de \\ luz y tamaño de claro en un bosque degradado en el centro sur de Los Andes de Chile
}

\author{
Pablo J Donoso a*, Daniel P Soto a, Rafael E Coopman a, Silvia Rodríguez-Bertos ${ }^{\text {b }}$ \\ *Corresponding author: ${ }^{a}$ Universidad Austral de Chile, Facultad de Ciencias Forestales y Recursos Naturales, \\ Instituto de Silvicultura, Valdivia, Chile, tel.: +56 63 221189, fax: +56 63 221230, pdonoso@uach.cl \\ b Universidad Politécnica de Madrid, EUITF, Ciudad Universitaria, 28040 Madrid, España.
}

\begin{abstract}
SUMMARY
The Andes of south-central Chile $\left(38-41^{\circ} \mathrm{S}\right)$ were once dominated by highly productive and valuable forests mainly dominated by Nothofagus dombeyi and N. alpina, but their exploitation led to extensive areas at present covered by high-graded stands. Although these tree species exhibit a light-demanding character and naturally grow in regions with severe winters, they show high mortality when planted in open areas with frequent spring frosts. The effect of light intensity and gap size on survival, size and form of $N$. dombeyi and $N$. alpina seedlings, planted in a high-graded stand, was analyzed. Direct and diffuse light (measured through hemispheric photographs) and effective gap area (range from 40 to $734 \mathrm{~m}^{2}$ ) were estimated in 23 forest gaps, which were divided into small, medium and large for each species (12 gaps for $N$. dombeyi and 11 gaps for $N$. alpina). After two growing seasons, mean survival of $N$. dombeyi was $>95 \%$ and not significantly different among gap categories; in $N$. alpina there was complete survival in medium-sized gaps, which was significantly different from survival in the larger and smaller gaps. Growth of Nothofagus dombeyi significantly increased with gap size and light availability; a phenomenon which did not occur in N. alpina. Nothofagus alpina experienced a lower slenderness within larger gaps. This study suggests that rehabilitation of high-graded stands, based on plantations of genus Nothofagus, is an ecologically viable option although control of canopy and understory covers is required.
\end{abstract}

Key words: degradation, restoration, tree growth, survival, shade tolerance

\section{RESUMEN}

Los Andes del centro sur de Chile (38-41º $)$ estuvieron dominados por bosques altamente productivos y valiosos de (Nothofagus dombeyi y $N$. alpina, pero la explotación de estas especies llevaron a la existencia actual de grandes superficies cubiertas en el presente por bosques degradados. Aunque estas especies son demandantes de luz y naturalmente crecen en regiones con inviernos severos, ellas muestran altas tasas de mortalidad cuando son plantadas en zonas abiertas con heladas frecuentes de primavera. La luz difusa y directa (medida a través fotos hemisféricas) y el área efectiva de claros (rango de 40 a $734 \mathrm{~m}^{2}$ ) se estimaron en 23 claros de bosque, los cuales fueron divididos en pequeños, medianos y grandes para cada especie (12 claros para $N$. dombeyi y 11 para $N$. alpina). Luego de dos temporadas de crecimiento, la sobrevivencia promedio de $N$. dombeyi fue $>95 \%$ y no significativamente diferente entre las categoría de claro estudiadas; en N. alpina hubo sobrevivencia completa en los claros de tamaño medio, lo que fue significativamente diferente a la sobrevivencia reportada en claros chicos y grandes. El tamaño de $N$. dombeyi fue significativamente mayor en claros más grandes y con aumentos en la disponibilidad de luz. Las plántulas de Nothofagus alpina no fueron afectadas en tamaño por la dimensión de los claros, pero experimentaron una menor esbeltez en claros grandes. Este estudio sugiere que la rehabilitación de bosques degradados, basada en plantaciones del género Nothofagus, es ecológicamente una opción viable aunque ello requiere control de la cobertura de copas y del sotobosque.

Palabras clave: degradación, restauración, crecimiento, sobrevivencia, tolerancia a la sombra.

\section{INTRODUCTION}

Degradation of natural forests due to exploitation is overshadowed by deforestation, in spite of being the major driver of losses of ecosystem goods and services, mainly in regions of the developing world (Nahuelhual et al. 2007). Particularly in old-growth forests, degradation is caused by high-grading which consists in the removal of the most commercially valuable trees, leaving a residual stand composed of poor timber quality individuals (Nyland 2006). This practice implies short-term economic benefits without any consideration of the diversity, regeneration and development of the growing stock left for the future forest. As a consequence, old-growth forests lose their original composition, structure and timber productivity, as well as many of the ecological services they once provided. In Chile, by 
the end of last century around $51 \%$ of an area of $8.2 \mathrm{mi}-$ llion hectares of second- and old-growth native forests had been exploited through high-grading; whereas only 5 to $25 \%$ of harvested stands showed sustainable management (Lara et al. 1998, and references therein).

The Andes of south-central Chile $\left(38-41^{\circ} \mathrm{S}\right)$ used to be covered by old-growth forests dominated by both, the shade-intolerant Nothofagus dombeyi ((Mirb.) Oerst.) and the shade-midtolerant Nothofagus alpina ((Phil.) Dim. et Mil.) (Donoso et al. 1986, 2006ab, Weinberger and Ramírez 2001). These early successional species form even-aged stands in sites where frequency of large-scale disturbances (e.g., landslides, fires ignited following volcanic eruptions and massive tree fall due to windstorms) is shorter than life-span of these Nothofagus species, allowing these species to maintain their dominance in the landscape. In absence of such exogenous perturbations, late-successional, shade-tolerant trees tend to become established under the canopy and to successionally replace Nothofagus species (Veblen et al. 1980, 1996, Donoso et al. 1986, Donoso 1993). As a consequence of severe overexploitation, currently these highly commercially valuable forests have lost biomass, density and productivity; large Nothofagus spp. trees are almost absent and less valuable shade-tolerant trees are dominant (Donoso 1993). The understory is occupied by a thick and continuous cover of Chusquea culeou (E. Desv.); a bamboo that prevents tree regeneration (Lusk 2001, Muñoz and González 2009). Overall, these high-graded areas meet all the characteristics of degraded stands described by Nyland (2006).

Considering that it is urgent to implement strategies to reduce both processes of deforestation and degradation, it is essential to search for the best options to recover the productivity of current high-graded forests. This process has to be conducted with locally supported options that, in addition to augmenting the natural capital, will generate jobs and improve livelihoods and the quality of life of all in the economy (sensu Aronson et al. 2006). Planting $N$. dombeyi and N. alpina in these high-graded forests seems one interesting option. These Nothofagus species are naturally adapted to mild climates within temperate regions in Chile and Argentina (Donoso et al. 2006ab), and due to their rapid growth and good expected economic returns in open-field plantations (Donoso et al. 2011, and references therein), they have been introduced in other regions of similar climates, with the most successful experience being that in southwest England and Wales (Matthews et al. 1989). However, open-field plantations of these species on abandoned artificial pasturelands in the Andes of south-central Chile where severe spring frosts occur (> 650 m a.s.1.; Donoso et al. 2007, Soto et al. 2009) or in the west of England and Wales have had severe mortality or damage. Considering that partial shade from forest canopies can protect seedlings from frosts (Slot et al. 2005) and changes the intensity of direct and diffuse incident light (Norman et al. 1971), it might be possible to suc- cessfully plant $N$. dombeyi and $N$. alpina in high-graded forests. However, considering that the species are of low shade tolerance, the challenge is to find the proper combination of canopy protection and light availability for optimum performance of planted seedlings of Nothofagus species.

In this study we report the first experience with plantations under canopy gaps in high-graded forests in the Chilean Andes, where the aim is to rehabilitate Nothofagus-dominated forests that were once characteristic of this region. We evaluated the performance of $N$. dombeyi and $N$. alpina seedlings two years after being planted in small- and middle-sized gaps in a high-graded forest stand. We predict a higher survival and growth response to light avaiability and gap size of $N$. dombeyi due to its lower shade tolerance compared with N. alpina (Donoso et al. 2006ab). Hence, our main objective was to determine the relationship between gap size and light availability and the effects of these variables upon survival and growth of planted $N$. dombeyi and $N$. alpina seedlings in the south-central Andes of Chile.

\section{METHODS}

Study site. The study was carried out in a 10-ha high-graded forest that was harvested some 50 years ago in the San Pablo de Tregua experimental forest of the Universidad Austral of Chile in the Andes ( $39^{\circ} 35^{\prime} \mathrm{S}, 72^{\circ} 05^{\prime} \mathrm{W}$; $650 \mathrm{~m}$ a.s.l.). The original old-growth forest likely had a structure similar to that reported for these type of Andean forests by Veblen et al. (1980) and Donoso et al. (1986) in their descriptions of pristine old-growth forests in the Province of Valdivia; i.e. forests with a basal area close to $100 \mathrm{~m}^{2}$ ha $^{-1}$ and an emergent tier of Nothofagus species ( $N$. dombeyi and $N$. alpina) above a canopy of the more shade-tolerant species (Laureliopsis philippiana (Looser) Schodde., Saxegothaea conspicua Lindl. and Dasyphyllum diacanthoides (Less.) Cabr.). An inventory of three $1,000 \mathrm{~m}^{2}$ plots in the high-graded forest stand used in this study (figure 1) shows large $20-25 \mathrm{~m}$ tall trees of L. philippiana and S. conspicua (species that had little commercial value by the time of harvest) and patchy distributed $N$. alpina trees of smaller diameters, which likely regenerated or remained (due to their small size by the time of harvest) following the cut. The stand is growing on a south to southwest facing slope. Its basal area is currently $c a$. $48 \mathrm{~m}^{2} \mathrm{ha}^{-1}$. The low number of small trees even of the most shade-tolerant species is likely the result of the development of dense thickets of $C$. culeou in the understory that has prevented forest regeneration following forest degradation. In 2000 C. culeou had a synchronous death, hence by the time of implementing this study through plantations in the understory (October 2007), there was a large quantity of dead biomass of C. culeou and the new stems of C. culeou had on average $3 \mathrm{~m}$ in height (compared to the 6 - 9 m they can reach; Lusk 2001). 


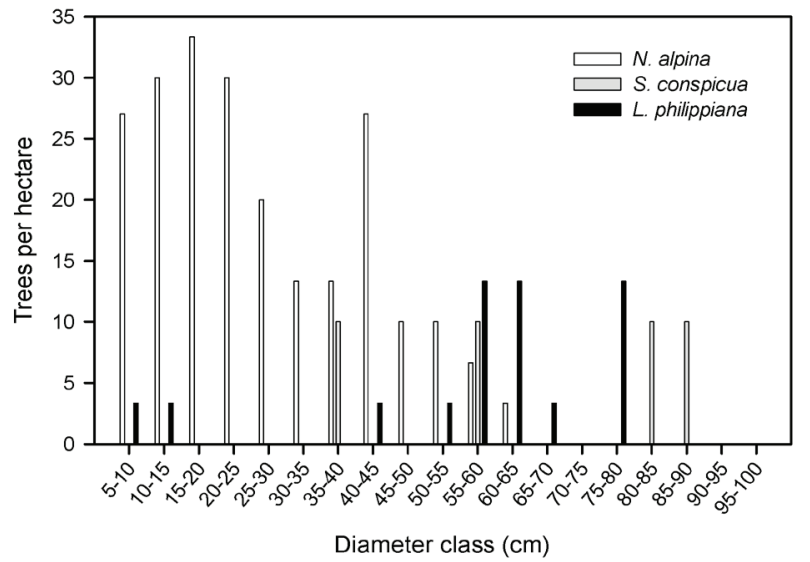

Figure 1. Diameter distribution of the high-graded mature forest stand in which $N$. dombeyi and $N$. alpina seedlings were planted in gaps of different sizes in the San Pablo de Tregua experimental forest.

Distribución diamétrica del rodal de bosque maduro degradado en el que plántulas de $N$. dombeyi y $N$. alpina fueron plantados en claros de distinto tamaño, predio San Pablo de Tregua.

Soils are derived from modern volcanic ashes (Acrudoxic hapludand), have a medium texture through the entire profile, with a pumice horizon over basaltic-andesitic rocks (CIREN 1999). This soil has a high water retention capacity (> $250 \mathrm{~mm}$ in $1 \mathrm{~m}$ depth) and total nitrogen content $(0.97 \pm 0.07 \%)$, and a carbon/nitrogen relation of $11.6 \pm 0.3$ (Donoso et al. 2007). However, it also has a high phosphorus retention and aluminum levels due to the presence of alophan. The climate according to Köppen is coastal oceanic with a Mediterranean influence, with short and dry summers and humid winters. The annual precipitation, mostly rainfall, ranges between 3,863 and 4,849 mm (Oyarzún et al. 2011). Mean annual temperature is $11^{\circ} \mathrm{C}$, while the mean for the coldest month (August) is $5{ }^{\circ} \mathrm{C}$ and for the warmest (February) $16^{\circ} \mathrm{C}$. There are 30 - 50 annual frosts (minimum temperatures $<0{ }^{\circ} \mathrm{C}$ ), concentrated from August through September (Soto et al. 2009).

Selection of gaps. We selected 23 gaps within the high-graded stand, which ranged in size from 40 to $734 \mathrm{~m}^{2}$. In 12 of these gaps we planted $N$. dombeyi and in 11 we planted $N$. alpina; for further analyses we divided these gaps into size categories, which were named small (four for N. dombeyi and five for $N$. alpina), medium (five for N. dombeyi and three for N. alpina) and large (three for each species). Gap size was measured by taking the distance from the center of the gap to every vertical tree crown projection (effective gap; Runkle 1992); combining this with the compass direction of the line (azimuth from the center of the plot to the crown edges of each tree around the gap; figure 2). Equation 1 was used to calculate the effective area of gaps (Fajardo and de Graaf 2004).

Gap area $\left(\mathrm{m}^{2}\right)=\sum\left(0.5 * d i^{*}(d j * \cos (90-a i))\right)$

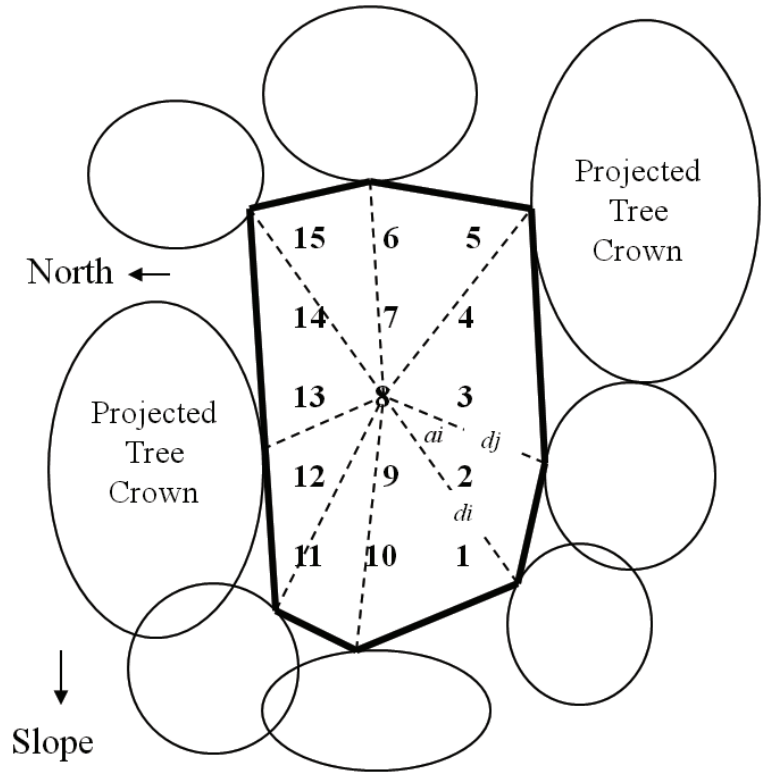

Figure 2. Schematic layout of gaps, crown projection of remnant trees (open circles), and the plantation of $N$. dombeyi and N. alpina in the gaps. The representation of polar coordinates (dashed lines) is shown for the predicted effective gap (sensu Runkle 1992). Spots from which photographs were taken to predict gap light transmission indices with the GLA (Gap Light Analyzer) were the center (seedling 8), the north edge (seedling 10), and the south edge (seedling 6 ) of the gaps. $d i$ is the distance from the center to each crown tree projected to the gap $i$ (in $\mathrm{m}$ ); $d j$ is the distance from the center to the contiguous crown tree $j$ (in $\mathrm{m}$ ) and $a i$ is the angle formed between both crown trees.

Esquema de los claros, proyección de copas de los árboles remanentes (círculos abiertos), y plantación de $N$. dombeyi y $N$. alpina en los claros. La representación de coordenadas polares (líneas discontinuas) se muestra para el área de claro efectivo (sensu Runkle 1992). Los puntos desde los cuales se tomaron las fotografías para predecir la transmisión de luz con el GLA (Gap Light Analyzer) fueron el centro (plántula 8), el borde norte (plántula 10), y el borde sur (plántula 6) de los claros. di es la distancia desde el centro de cada copa de árbol proyectada en el claro $i$ (en m); dj es la distancia desde el centro de la copa del árbol contiguo $j$ (en m) y ai es el ángulo formado entre las dos copas de los árboles.

where $d i$ is the distance from the center to each crown tree projected to the gap $i$ (in $\mathrm{m}$ ); $d j$ is the distance from the center to the contiguous crown tree $j$ (in $\mathrm{m}$ ); and $a i$ is the angle formed between both crown trees (figure 2). Minimum gap size was similar for both species, but the mean and maximum gap sizes were larger for $N$. dombeyi (table 1).

Planting design. Seedlings were planted in gaps (an open area $>25 \mathrm{~m}^{2}$ surrounded by trees (sensu Veblen 1985)). At the end of October 2007, we planted 15 one-year old containerized seedlings of $N$. dombeyi in each of the 12 gaps and the same number of $N$. alpina seedlings in each of the 11 gaps. These seedlings were planted inside each gap at a 2 by $3 \mathrm{~m}$ distance in a rectangular design (figure 2). Seedlings ranged in total height between 35 and $45 \mathrm{~cm}$ and in rootcollar diameter between 3 and $4 \mathrm{~mm}$. Seedlings were 
Table 1. General characteristic of gaps planted with $N$. dombeyi and $N$. alpina in the San Pablo de Tregua experimental forest. Numbers in each cell (except for number of gaps) represent the mean \pm the standard deviation plus the range, in parenthesis.

Características generales de los claros plantados con N. dombeyi and N. alpina en San Pablo de Tregua. Los números en cada celda (excepto para number of gaps) representan la media \pm desviación estándar más el rango, en paréntesis.

\begin{tabular}{lcc}
\hline \multicolumn{1}{c}{ Variable } & Nothofagus dombeyi & Nothofagus alpina \\
\hline Number of gaps & 12 & 11 \\
Gap size $\left(\mathrm{m}^{2}\right)$ & $344.5 \pm 228.6(45.8-734.2)$ & $274.3 \pm 182.8(42.9-484.9)$ \\
$\quad$ Small & $124.6 \pm 63.1(45.8-184.6)$ & $75.9 \pm 22.4(42.9-98.1)$ \\
$\quad$ Medium & $327.1 \pm 85.2(223.9-440.3)$ & $372.3 \pm 56.6(315.3-423.9)$ \\
$\quad$ Large & $666.8 \pm 116.6(532.2-734.2)$ & $474.5 \pm 18.0(453.7-484.9)$ \\
Canopy openness $(\%)$ & $22.8 \pm 6.9(11.6-31.6)$ & $19.5 \pm 5.7(12.4-30.8)$ \\
LAI $\left(\mathrm{m}^{2} \mathrm{~m}^{2}\right)$ & $1.8 \pm 0.43(1.3-2.6)$ & $1.9 \pm 0.31(1.3-2.4)$ \\
Direct light transmission $\left(\mathrm{mol} \mathrm{m}^{2} \mathrm{~d}^{-1}\right)$ & $2.47 \pm 1.47(0.47-5.57)$ & $1.71 \pm 1.44(0.13-5.46)$ \\
Diffuse light transmission $\left(\mathrm{mol} \mathrm{m}^{2} \mathrm{~d}^{-1}\right)$ & $4.53 \pm 1.37(2.32-6.20)$ & $3.85 \pm 1.12(2.44-5.98)$ \\
Total light transmission $\left(\mathrm{mol} \mathrm{m}^{2} \mathrm{~d}^{-1}\right)$ & $6.97 \pm 2.48(3.23-11.28)$ & $5.56 \pm 2.27(3.19-11.44)$ \\
\hline
\end{tabular}

produced with seeds collected from trees in the San Pablo de Tregua experimental forest. Seedlings' production followed the protocol described in Bustos et al. (2008).

Before planting, weeds (mostly C. culeou) in gaps were manually removed within 1-m wide strips in which seedlings were established. No seedlings were planted below tree crowns at the gap edges, and each seedling was measured for root-collar diameter (2 cm above the ground) and height following plantation. Two growing seasons after plantation, all live planted seedlings were recorded to calculate survival rates, and their root-collar diameter and total plant height was measured. The stem volume was later calculated from root-collar diameter and plant height using a cone formula [2]. The ratio between plant height and root-collar diameter was used to calculate the slenderness index, where lower values tend to reflect seedlings with a better biomass distribution and health (Bustos et al. 2008).

Stem volume $\left(\mathrm{cm}^{3}\right)=\pi * \mathrm{RCD}^{2 *} \mathrm{TH} / 12$

where: $\mathrm{RCD}=$ root collar diameter $(\mathrm{cm}) ; \mathrm{TH}=$ total height (cm) and $\pi=$ constant.

Gap light availability. Gap light availability was estimated by hemispherical photographs, using a Coolpix 4500 digital camera (Nikon CO., Japan) with a FCE-8 fisheye lens that has a $182^{\circ}$ field of view (Nikon CO., Japan). Three photographs per gap were taken at the apex of seedlings located in the center, north and south sides of the planted area (figure 2). Photographs were taken under homogeneous diffuse sky light conditions in March 5, 2009. The resulting photographs were analyzed for light transmission indices (daily total, direct and diffuse transmitted radiation through the canopy) and the percentage of canopy openness with the Gap Light Analyzer 2.0 software (GLA: Frazer et al. 1999). GLA local light environment input parameters were solar constant: $1,370 \mathrm{~W} \mathrm{~m}^{-2}$, cloudiness index: 0.5 , spectral fraction: 0.45 , bean fraction: 0.85 , clear sky transmission coefficient: 0.65 and standard overcast sky-regions brightness. Light transmission was, on average, higher in gaps planted with $N$. dombeyi. Canopy openness and leaf area index (LAI) were similar for both species (table 1).

Statistical analyses. Mean values per plot for canopy openness and daily total, direct and diffuse transmitted radiation through the canopy were used for analyses. Sample units corresponded to the mean of 15 measurements on 15 plants per gap, or less in case of some mortality. Secondorder polynomial regression analyses were conducted to assess the relationship between gap size and canopy openness, and between gap size and daily total, direct and diffuse transmitted radiation through the canopy. Linear regression analyses were conducted to assess the relationship between light availability and size of $N$. dombeyi and $N$. alpina seedlings. Size and survival of seedlings of each species were evaluated in each gap. To evaluate the effect of gap size on seedling survival, survival percentage per gap was previously transformed with an arcsine squareroot equation to meet normality. However, even so the data was not normally distributed and we used a non-parametric Kruzkal-Wallis (H-test) ANOVA and Dunn's test for gap size separation when the $H$-test was significant $(P<0.05)$. To evaluate size, we used ANOVA and the Tukey test for post hoc analyses. Differences between treatments were considered significant at $P<0.05$. For these statistical analyses we used the SigmaPlot 11.0 package.

\section{RESULTS}

Relationship between gap size and light availability. Canopy openness $\left(\mathrm{R}^{2}=57.2 \%\right)$ and total radiation $\left(\mathrm{R}^{2}=49.4 \%\right)$ increased with gap size (figures $3 \mathrm{~A}$ and $3 \mathrm{~B}$; table 2). Howe- 


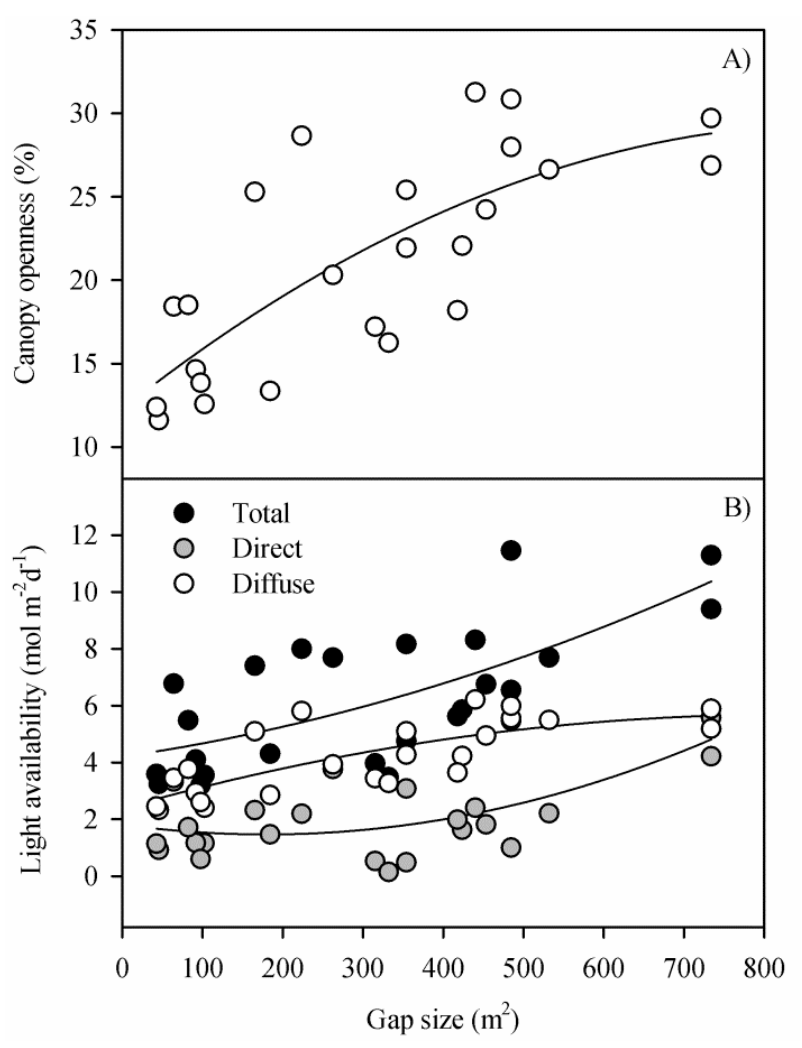

Figure 3. Relationships between gap size and light availability in a high-graded stand in the San Pablo de Tregua experimental forest. A) Second-order polynomial regression between canopy openness and gap size. B) Second-order polynomial regressions between total, direct and diffuse daily transmitted radiation and gap size.

Relaciones entre disponibilidad de luz y tamaño de claro en un bosque andino degradado. A) Regresión polinomial de segundo orden entre abertura de dosel y tamaño de claro. B) Regresión polinomial de segundo orden entre transmisión diaria de radiación directa y difusa y tamaño de claro.

ver, the best relationship was obtained between gap size and diffuse radiation $\left(\mathrm{R}^{2}=56.7 \%\right)$, while the poorest was with direct radiation $\left(\mathrm{R}^{2}=38.3 \%\right.$; figure $3 \mathrm{~B}$, table 2$)$.

Effects of light availability upon the performance of seedlings. After two growing seasons, plant height of N. dombeyi significantly increased with total, direct and diffuse radiation (figure $4 \mathrm{~A}$ ). The increases in plant height were better explained by total $\left(\mathrm{R}^{2}=0.595 ; P=0.003\right)$ and direct $\left(\mathrm{R}^{2}=0.508 ; P=0.009\right)$ radiation than with diffuse radiation $\left(\mathrm{R}^{2}=0.405 ; P=0.026\right)$. Plant height of $N$. alpina was not affected by total $\left(\mathrm{R}^{2}=0.0593 ; P=0.471\right)$, direct $\left(\mathrm{R}^{2}=0.0231 ; P=0.656\right)$ or diffuse $\left(\mathrm{R}^{2}=0.0485 ; P=0.515\right)$ radiation (figure 4B). Root-collar diameter of $N$. dombeyi significantly increased with total $\left(\mathrm{R}^{2}=0.630 ; P=0.002\right)$, direct $\left(\mathrm{R}^{2}=0.526 ; P=0.008\right)$ and diffuse $\left(\mathrm{R}^{2}=0.432\right.$; $P=0.020$ ) radiation (figure $4 \mathrm{C}$ ). Conversely, root-collar diameter of $N$. alpina was not affected by total $\left(\mathrm{R}^{2}=0.217\right.$; $P=0.148)$, direct $\left(\mathrm{R}^{2}=0.0354 ; P=0.580\right)$ or diffuse $\left(\mathrm{R}^{2}=0.271 ; P=0.101\right)$ radiation (figure $\left.4 \mathrm{D}\right)$.

Stem volume of $N$. dombeyi significantly increased with all types of available radiation. It was better explained by total $\left(\mathrm{R}^{2}=0.574 ; P=0.004\right)$ and direct radiation $\left(\mathrm{R}^{2}=0.545 ; P=0.006\right)$ than by diffuse radiation $\left(\mathrm{R}^{2}=0.342 ; P=0.046\right.$; figure 5A). Stem volume of N. alpina was not affected by total $\left(\mathrm{R}^{2}=0.158 ; P=0.226\right)$, direct $\left(\mathrm{R}^{2}=0.0274 ; P=0.627\right)$ and diffuse radiation $\left(\mathrm{R}^{2}=0.192\right.$; $P=0.177$; figure 5B). Slenderness of $N$. dombeyi seedlings was not significantly affected by radiation (figure 5C), but slenderness of $N$. alpina seedlings significantly decreased with diffuse radiation $\left(\mathrm{R}^{2}=0.393 ; P=0.039\right.$; figure 5D).

Relationships between gap size and performance of seedlings. There were no significant differences in survival of $N$. dombeyi among gaps, but in $N$. alpina the medium-sized gaps had a significantly higher rate of survival than both the smaller and larger gaps (table 3). Plant height and root-collar diameter of $N$. dombeyi seedlings significantly increased with gap size (figure 6). Seedlings reached on average $85 \mathrm{~cm}$ in plant height in small gaps, and $150 \mathrm{~cm}$ in large gaps; in root-collar diameter seedlings had $7 \mathrm{~mm}$ in small gaps and $13 \mathrm{~mm}$ in large gaps. These differences in plant height and root-collar diameter also led to a significantly greater stem volume of seedlings in large gaps $\left(290 \mathrm{~cm}^{3}\right.$ vs. $50 \mathrm{~cm}^{3}$ in small gaps). The only variable not affected by gap size in $N$. dombeyi was slenderness (figure 6). On the contrary, plant height, root-collar diameter and volume of seedlings of N. alpina were not significantly affected by gap size, although root-collar diameter and stem volume showed an increasing growth trend with larger gaps (figure 6). However, N. alpina seedlings had a lower slenderness in large gaps.

Table 2. Summary of second-order polynomial regressions fitted for predicted canopy openness and for light partitioning as a function of gap size $\left(\mathrm{m}^{2}\right)$ in a high-graded stand in the San Pablo de Tregua experimental forest.

Resumen de regresiones polinomiales de segundo orden ajustadas para estimar apertura de copas y para partición de luz en función del tamaño de claro $\left(\mathrm{m}^{2}\right)$, en un bosque de San Pablo de Tregua.

\begin{tabular}{lccc}
\hline Dependent variable & Equation & $\mathrm{R}^{2}$ & $P$-value \\
\hline Canopy openness $(\%)$ & $12.269+0.038$ (gap size) $-2.117\left(\right.$ gap size $\left.^{2}\right)$ & 0.572 & $<0.0001$ \\
Total light $\left(\mathrm{mol} \mathrm{m}^{-2} \mathrm{~s}^{-1}\right)$ & $4.200+4.112$ (gap size) $+5.845\left(\right.$ gap size $\left.^{2}\right)$ & 0.494 & $<0.0001$ \\
Direct light $\left(\mathrm{mol} \mathrm{m}^{-2} \mathrm{~s}^{-1}\right)$ & $1.814-3.891$ (gap size) $+1.085($ gap size $)$ & $0.383<0.0001$ \\
Diffuse light $\left(\mathrm{mol} \mathrm{m}^{-2} \mathrm{~s}^{-1}\right)$ & $2.383+7.976$ (gap size) $-4.815\left(\right.$ gap size $\left.^{2}\right)$ & 0.567 & $<0.0001$ \\
\hline
\end{tabular}




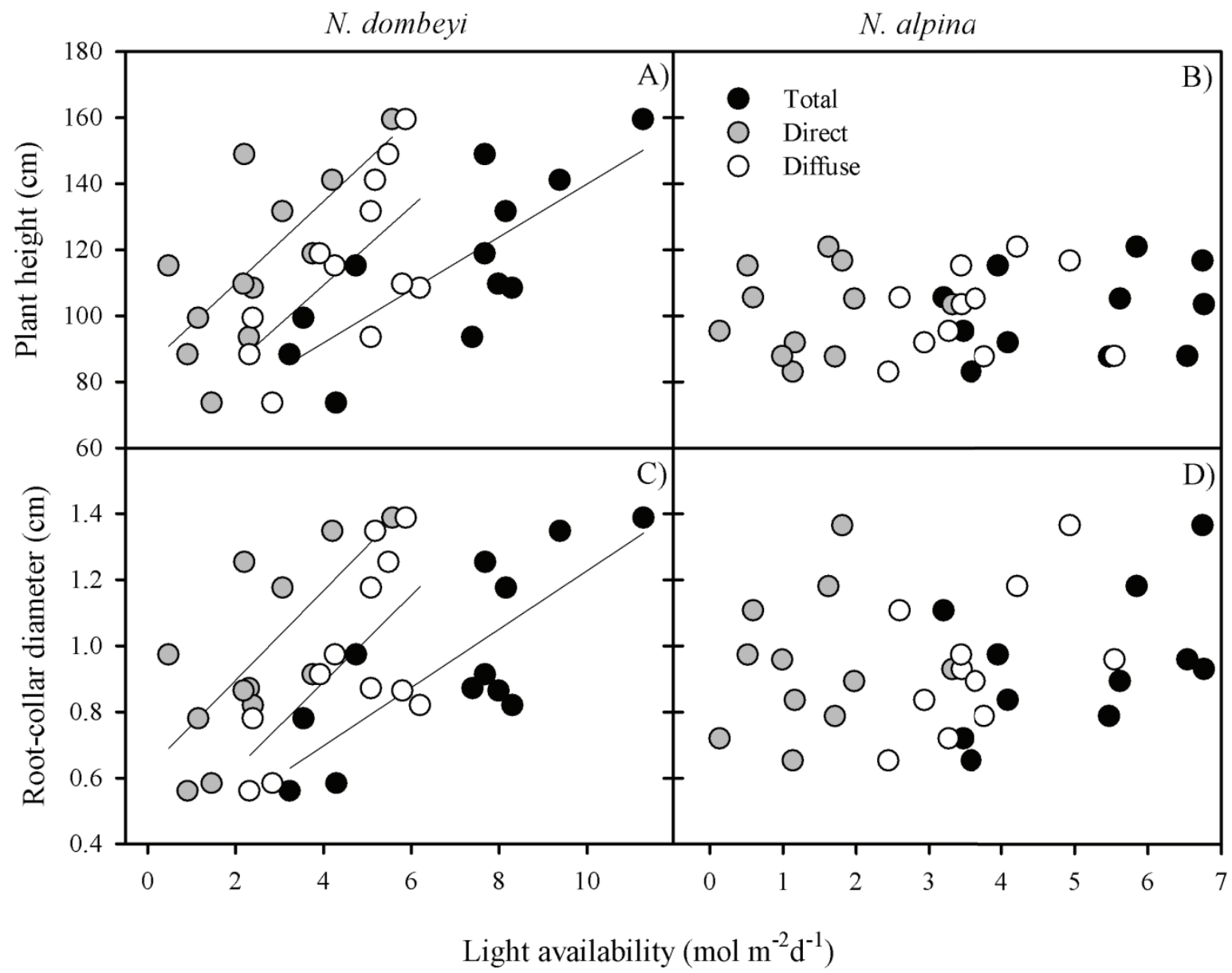

Figure 4. Relationships between light availability and plant height (PH) and root-collar diameter (RCD) of $N$. dombeyi and $N$. alpina seedlings planted in different gap sizes in an Andean high-graded mature forest (12 gaps for $N$. dombeyi and 11 gaps for $N$. alpina). Regressions among total, direct and diffuse daily transmitted radiation with $\mathrm{PH}$ and RCD were significant for N. dombeyi (A and C) but not for $N$. alpina (B and D). Lines for the relationships are only shown when coefficients of determination were significant.

Relación entre disponibilidad de luz y crecimiento en altura y diámetro de cuello de plántulas de $N$. dombeyi y $N$. alpina plantadas en claros de distinto tamaño en un bosque madura andino degradado. Las regresiones entre radiación diaria transmitida total, directa y difusa con altura total y diámetro de cuello fueron significativas para $N$. dombeyi (A y C) pero no para $N$. alpina (B y D). Las líneas para las relaciones solo se muestran cuando los coeficientes de determinación fueron significativos.

Table 3. Survival (mean $\% \pm$ standard deviation) of seedlings, by species, in the study gaps as a function of gap size categories in a high-graded stand in the San Pablo de Tregua experimental forest.

Sobrevivencia (media \% \pm desviación estándar) de plántula, por especie, en los claros estudiados en función de las categorías de tamaño de claros en un bosque degradado en San Pablo de Tregua.

\begin{tabular}{lcccc}
\hline Gap size $\left(\mathrm{m}^{2}\right)$ & N. dombeyi & $\mathrm{n}$ & N. alpina & $\mathrm{n}$ \\
\hline Small & $98.3 \pm 3.3$ & 4 & $96.0 \mathrm{~b} \pm 3.6$ & 4 \\
Medium & $94.7 \pm 8.7$ & 5 & $100.0 \mathrm{a} \pm 0$ & 4 \\
Large & $94.5 \pm 9.6$ & 3 & $86.7 \mathrm{~b} \pm 6.7$ & 3 \\
& & & & \\
$H$-value & $0.392 \mathrm{~ns}$ & & $7.668^{*}$ & \\
& & & &
\end{tabular}

ns: nonsignificant, ${ }^{*} P<0.05$

\section{DISCUSSION}

Differential responses of $\mathrm{N}$. dombeyi and $\mathrm{N}$. alpina to light and gap size. In the present study, canopy openness was only $10-15 \%$ in the small gaps and 25 - $30 \%$ in the large gaps, and the quantity of light transmitted to the apex of seedlings (affected also by the understory removal) ranged from 3.20 to $11.45 \mathrm{~mol} \mathrm{~m}^{-2} \mathrm{~d}^{-1}$. These conditions were not ample enough to reflect any major effects of gap size on mortality of two-year old planted $N$. dombeyi and $N$. alpina seedlings (survival range from 84 to $100 \%$ ); although in medium-sized gaps the survival of $N$. alpina seedlings was significantly greater than in small and large gaps. Gap size did, however, significantly affect the size of $N$. dombeyi and the quality (slenderness) of $N$. alpina when light availability decreased within the range of gap sizes evaluated. These results support our prediction that $N$. dombeyi shows a higher growth responsiveness to light than 


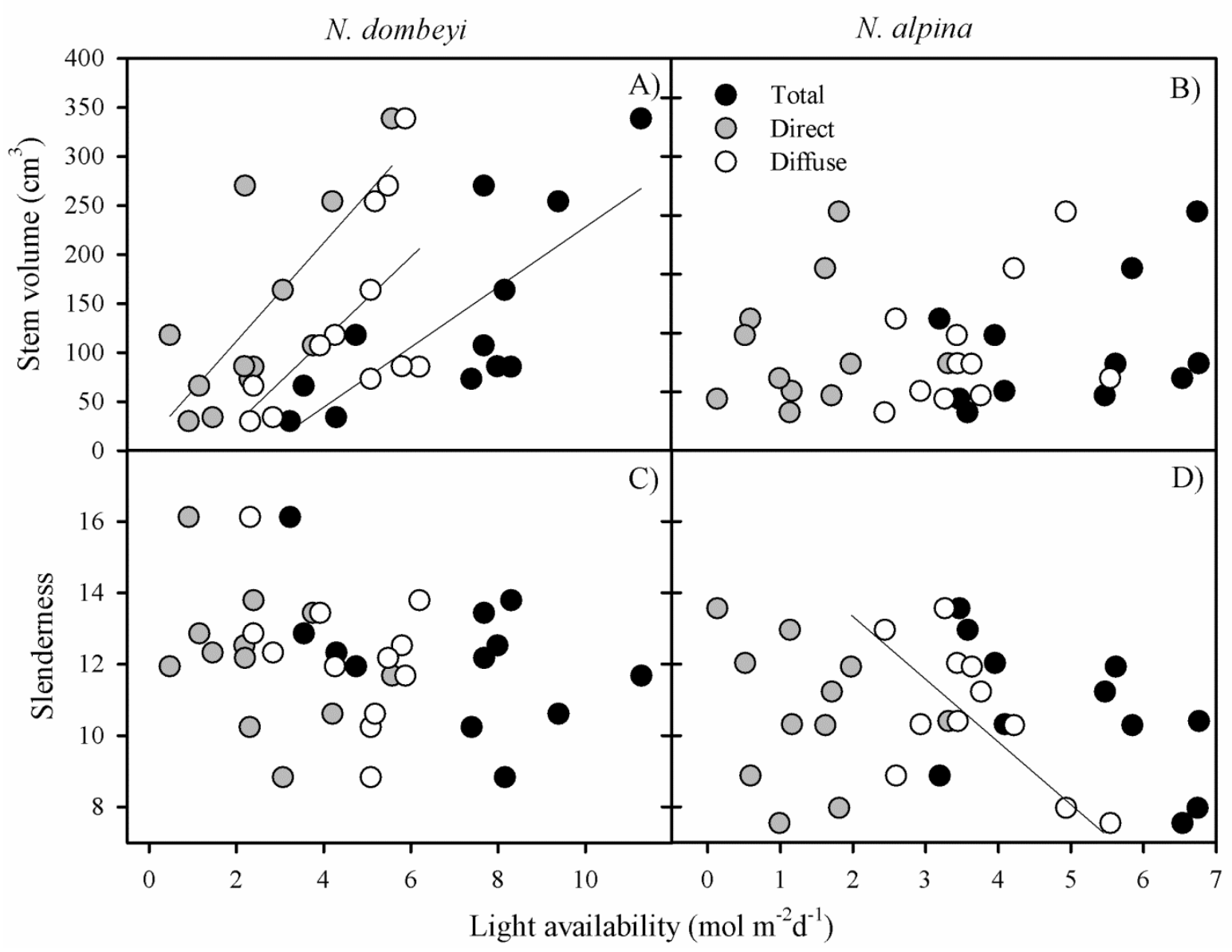

Figure 5. Relationships between light availability and stem volume (A and B) and slenderness (C and D) of N. dombeyi and N. alpina seedlings planted in different gap sizes in a high-graded stand in the San Pablo de Tregua experimental forest. Regressions among total, direct and diffuse daily transmitted radiation with stem volume for $N$. dombeyi (A), and between direct radiation and slenderness of $N$. alpina (D) were significant. Lines for the relationships are only shown only when coefficients of determination were significant. Relaciones entre disponibilidad de luz y crecimiento en volumen (A y B) y esbeltez (C y D) para plántulas de N. dombeyi y N. alpina plantadas en distintos claros de bosque. Sólo la regresión entre radiación diaria transmitida con el volumen de $N$. dombeyi (A), y entre radiación directa y esbeltez para N. alpina (D) fueron significativas. Las líneas para las relaciones sólo se muestran para cuando los coeficientes de determinación fueron significativos.

N. alpina, and reflect the more shade intolerant character of $N$. dombeyi (Donoso et al. 2006ab).

The results indicate that after the two first growing seasons the performance of $N$. dombeyi and $N$. alpina was in general poor in the smallest gaps as reflected in size and/ or quality of the seedlings. Seedlings of $N$. dombeyi performed better in larger gaps, and those of $N$. alpina in both medium-sized gaps (complete survival) and large gaps (bigger plants with significantly lower slenderness). These results support earlier suggestions that natural regeneration of $N$. dombeyi would respond better to larger gaps and that of $N$. alpina to relatively smaller gaps (Weinberger and Ramírez 2001). We have to consider, however, that the mean size of the large-gap category used for $N$. alpina had a rather small difference with that of the medium-gap category (only $102 \mathrm{~m}^{2}$ ); hence, such small difference presents a limitation to interpret the effects of gap size upon the performance of $N$. alpina.
Comparison of growth with other plantations. Growth rates derived from the present study are lower than those reported in open field plantations established on abandoned pasturelands at lower elevations at the same latitude (Wienstroer et al. 2003, Donoso et al. 2011). However, they are higher than those reported for open-field plantations in the same experimental forest (Donoso et al. 2007). Yet, most important is the fact that the plantations in gaps evaluated in the present study had nearly complete survival, in contrast with the high mortality rates reported for plantations of these species in open fields at the same elevation described in this study after one growing season (53-79 \% survival; Donoso et al. 2007) and two growing seasons (37 \% survival; Soto et al. 2009). This finding is consistent with previous studies that show that shelter from neighboring vegetation (Álvarez and Lara 2008, Soto et al. 2009) or overstory vegetation (Grosse 1988) promotes a better performance of seedlings of these species, in spite 


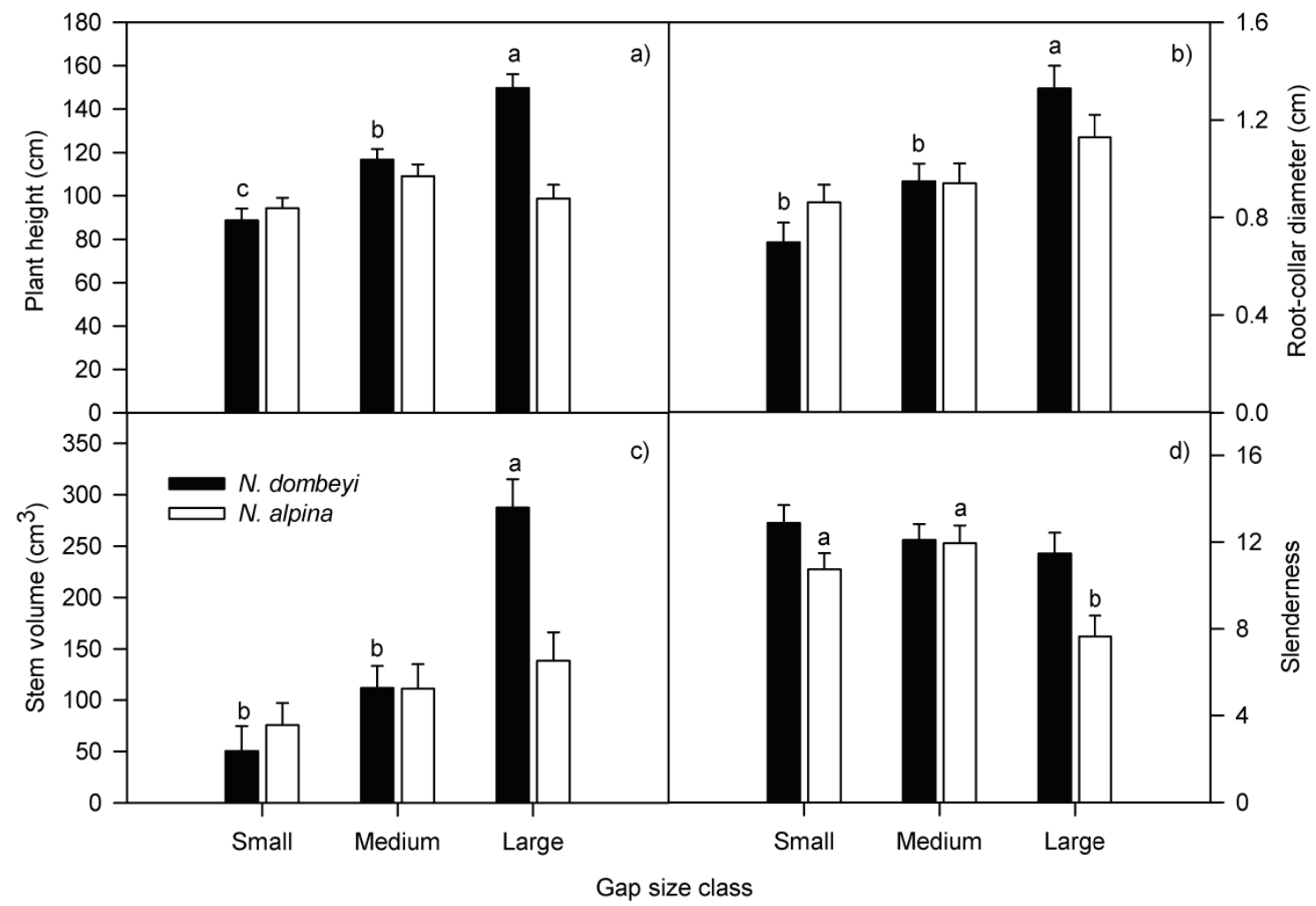

Figure 6. Size of planted $N$. dombeyi and N. alpina seedlings according to gap size categories in a high-graded stand in the San Pablo de Tregua experimental forest. Measured variables were A) Plant Height, B) Root-collar diameter, C) stem volume, and D) slenderness. Different letters on top of the bars (mean \pm SD) indicate significant differences.

Respuestas en crecimiento de plántulas de $N$. dombeyi y $N$. alpina de acuerdo a categoría de tamaño de claros in en rodal estudiado. Las variables de crecimiento medidas fueron A) altura total (PH), B) diámetro de cuello (RCD), C) volumen, y D) esbeltez. Letras diferentes arriba de las barras (media \pm DS) indican diferencias significativas.

of their high resistance to low temperatures (Reyes-Díaz et al. 2005). The interaction between coldness and high light in open conditions in the Andes may be the cause of severe photo-damage of seedlings (Huner et al. 1998), which eventually determines the productivity and growth of trees at high altitude sites (Slot et al. 2005).

An opportunity to restore high-graded forests. We aimed in this study to find a proper combination of canopy protection and light availability for optimum performance of planted seedlings of Nothofagus species that naturally have a pioneer behavior and low shade-tolerance. Within the range of gap sizes tested in this study, our results suggest that plantations of $N$. dombeyi and $N$. alpina perform better than plantations established on abandoned pasturelands (i.e. open-field conditions) and that smaller gaps seem more detrimental for $N$. dombeyi. Although our results are geographically limited, they suggest that there is a chance to restore current high-graded Andean forests in south-central Chile with Nothofagus spp. plantations in gaps within these forests. We believe that at least these preliminary results could also be expected in the transitional zone of the Mediterranean to temperate climates that occurs between $38^{\circ}$ and $41^{\circ}$ where similar forests of the Coihue-Raulí-Tepa forest type occur (Donoso et al. 1986). Within this region there are naturally variations in climate (differences in latitude, elevation and aspect) and soils that determine some changes in species composition, but $N$. dombeyi and $N$. alpina are always among the dominant species (Donoso et al. 1986). Studies similar to the one presented in this article should be conducted throughout the region, in order to evaluate variations in the performance of Nothofagus spp. plantations in high-graded forests according to the macroenvironment as affected additionally by the microenvironment, i.e. especially gap sizes.

Implications for practice. Successful plantations of species mid-tolerant or intolerant to shade under the canopy of degraded or managed forests (e.g. with shelterwood silvicultural methods) seem possible, and sometimes necessary, especially when thickets of bamboos impede for decades the growth of tree species (Lusk 2001). We show in the present study that planting $N$. dombeyi and $N$. alpina in gaps was not only possible but so far also successful as measured by survival and growth rates. Successful results of plantations with these two Nothofagus species in the understory was 
also proved in the south west peninsula of England; another region of mild temperate climate, where these species were planted after the third thinning applied in a conifer forests (page 178 in Matthews 1989). These experiences show that managers must pay special care in controlling the amount of shade to which planted trees are exposed, especially considering that shade increases with canopy expansion through time (Niinemets 2007). The effect of the understory is also of great relevance. Nothofagus dombeyi is unable to regenerate naturally in gaps smaller than $1,500 \mathrm{~m}^{2}$ when there is a dense understory (Veblen 1985, Donoso 1993); nevertheless, where forests lack a thick understory (especially of Chusquea sp.), it is able to regenerate even under the closed canopy of old-growth forests (Pollmann and Veblen 2004). In the case of $N$. alpina, which can naturally regenerate in smaller gaps (Donoso 1993), the lack of competition in the understory also favors its growth (Donoso et al. 2006a). Overall, managers should most likely make decisions to rehabilitate or restore high-graded forest ecosystems based on the expected productivity and value of the future forest, which is a function of the species planted and their light requirements. In the case of this study it seems that restoration of the extensive areas of high-graded forests of the south-central Andes of Chile may be an attractive option considering the good growth and high value of $N$. dombeyi and $N$. alpina, in addition to their good reputation among landowners.

\section{ACKNOWLEDGEMENTS}

We thank the financial support from the FONDEF program (project D07I1034) of the Comisión Nacional de Investigación y Tecnología (CONICYT). RE Coopman thanks the Programa de Inserción Académica (PDA-24) of CONICYT.

\section{REFERENCES}

Álvarez C, A Lara. 2008. Crecimiento de una plantación joven en fajas con especies nativas en la Cordillera de Los Andes de la provincia de Valdivia. Bosque 29(3): 181-191.

Aronson J, AF Clewell, JN Blignaut, SJ Milton. 2006. Ecological restoration: A new frontier for nature conservation and economics. Journal of Nature Conservation 14: 135-139.

Bustos F, ME González, PJ Donoso, V Gerding, C Donoso, B Escobar. 2008. Efectos de distintas dosis de fertilizante de liberación controlada (Osmocote ${ }^{\circledR}$ ) en el desarrollo de plantas de coigüe, raulí y ulmo. Bosque 29(2): 155-161.

CIREN (Centro de Información de Recursos Naturales, CL). 1999. Estudio agrológico de la provincia de Valdivia X-Región. Descripción de suelos. Material y Símbolos. Santiago, Chile. CIREN. 199 p.

Donoso C. 1993. Estructura, Variación y Dinámica de Bosques Templados de Chile y Argentina. Ecología Forestal. Santiago, Chile. Editorial Universitaria. 369 p.

Donoso C, R Deus, JC Cockbaine, H Castillo. 1986. Variaciones estructurales del tipo forestal Coihue Raulí-Tepa. Bosque 7(1): 17-35.
Donoso P, C Donoso, P Marchelli, L Gallo, B Escobar. 2006a. Nothofagus alpina. In Donoso C ed. Las especies arbóreas de los bosques templados de Chile y Argentina. Autoecología. Valdivia, Chile. Marisa Cuneo Ediciones. p. 448-461.

Donoso P, C Donoso, C Navarro, B Escobar. 2006b. Nothofagus dombeyi. In Donoso C ed. Las especies arbóreas de los bosques templados de Chile y Argentina. Autoecología. Valdivia, Chile. Marisa Cuneo Ediciones. p. 423-432.

Donoso PJ, V Gerding, D Uteau, DP Soto, O Thiers, C Donoso. 2007. Crecimiento y mortalidad inicial de una plantación de Nothofagus dombeyi con diferentes dosis de fertilizantes en la Cordillera de Los Andes. Bosque 27(3): 249-255.

Donoso PJ, AA Muñoz, O Thiers, DP Soto, C Donoso. 2011. Effects of aspect and type of competition on the early performance of Nothofagus dombeyi and N. alpina in a mixed plantation in the Chilean Andes. Canadian Journal of Forest Research 41: 1075-1081.

Fajardo A, R de Graaf. 2004. Tree dynamics in canopy gaps in old-growth forests of Nothofagus pumilio in Southern Chile. Plant Ecology 173: 95-105.

Frazer GW, CD Canham, KP Lertzman. 1999. Gap Light Analyzer (GLA), version 2.0: Imaging software to extract canopy structure and gap light indices from true-colour fisheye photographs. New York, USA. Simon Fraser University, Burnaby, BC, and the Institute of Ecosystem Studies. 73 p.

Grosse H. 1988. Crecimiento de plantaciones con raulí - roble bajo dosel en dependencia del grado de luminosidad y fertilización. Ciencia e Investigacion Forestal 2: 13-30.

Huner NPA, G Öquist, V Hurry, M Krol S, Falk, M Griffith. 1998. Photosynthesis, photoinhibition and low temperature acclimation in cold tolerant plants. Photosynthesis Research 37: 19-39.

Lara, A. 1998. El catastro de vegetación nativa: la fuerza de los resultados. In Hoffmann A ed. La Tragedia del Bosque Chileno Adriana. Santiago, Chile. Editorial Ocho Libros Editores. p. 118-119.

Lusk CH. 2001. When is a gap not a gap? light levels and leaf area index in bamboo-filled gaps in a chilean rain forest. Gayana Botánica 58(1): 25-30.

Matthews JD. 1989. Silvicultural systems. Oxford, England. Clarendon Press. 284 p.

Muñoz AA, ME González. 2009. Patrones de regeneración arbórea en claros a una década de la floración y muerte masiva de Chusquea quila (Poaceae) en un remanente de bosque antiguo del valle central en el centro-sur de Chile. Revista Chilena de Historia Natural 82: 185-198.

Nahuelhual L, PJ Donoso, A Lara, D Núñez, C Oyarzún, E Neira. 2007. Valuing ecosystem services of Chilean temperate rainforests. Environment, Development and Sustainability 9: 481-499.

Niinemets Ü. 2007. Photosynthesis and resource distribution through plant canopies. Plant Cell and Environment 30: 1052-1071.

Norman JM, EE Miller, CB Tanner. 1971. Light intensity and sunfleck-size distributions in plant canopies. Agronomy Journal 63: 743-748.

Nyland RD. 2006. Rehabilitating cutover stands: Some ideas to ponder. In Kenefic LS and RD Nyland eds. Diameterlimit cutting in Northeastern Forests. Newtown Square, PA, USA. USDA Northeastern Research Station. General Technical Report NE-342. p. 47-51. 
Pollmann W, TT Veblen. 2004. Nothofagus regeneration dynamics in south-central Chile: a test of a general model. Ecological Monographs 74: 615-634.

Oyarzún C, R Godoy, J Staelens, PJ Donoso, N Verhoest. 2011. Seasonal and annual forest throughflow and stemflow in the Andean temperate rainforests. Hydrological Processes 25: 623-633.

Reyes-Díaz M, M Alberdi, F Piper, LA Bravo, LJ Corcuera. 2005. Low temperature responses of Nothofagus dombeyi (Mirb.) Blume and Nothofagus nitida (Phil.) Krasser, two evergreen species from South Central Chile. Tree Physiology 25: 1389-1398.

Runkle JR. 1992. Guidelines and sample protocol for sampling forest gaps. Portland, OR, USA. US Department of Agriculture. Forest Service General Technical Report PNWGTR-283. 44 p.

Slot M, C Wirth, JS Schumacher, GM J Mohren, O Shibistova, I LLoyd, I Ensminger. 2005.Regeneration patterns in boreal Scots pine glades linked to cold-induced photoinhibition. Tree Physiology 25: 1139-1150.

Soto DP, PJ Donoso, D Uteau, A Zuñiga-Feest. 2009. Environ- mental factors affect the spatial arrangement of survival and damage of out planted Nothofagus dombeyi seedlings in the Chilean Andes. Interciencia 34: 100-105.

Veblen TT, F Schlegel, B Escobar. 1980. Structure and dynamics of old-growth forests in theValdivian Andes, Chile. Journal of Ecology 68: 1-31.

Veblen TT. 1985, Forest development in tree fall gaps in the temperate rain forest of Chile. National Geographic Research 1: $161-184$

Veblen TT, C Donoso, T Kitzberger, AJ Rebertus. 1996. Ecology of Southern Chilean and Argentinean Nothofagus forest. In Veblen TT, RS Hall, J Read eds. The Ecology and Biogeography of Nothofagus forest. New Haven, USA. Yale University Press. p. 293-353.

Weinberger P, C Ramírez. 2001. Microclima y regeneración natural de raulí, roble y coihue (Nothofagus alpina, N. obliqua y N. dombeyi). Bosque 22(1): 11-26.

Wienstroer M, H Siebert, B Müller-Using. 2003. Competencia entre tres especies de Nothofagus y Pseudotsuga menziesii en plantaciones mixtas jóvenes, establecidas en la precordillera andina de Valdivia. Bosque 24(3): 17-30.

Recibido: 27.03.12

Aceptado: 02.08.12 